\title{
Pemuda, Perkawinan, dan Perubahan \\ Sosial di Indonesia
}

\author{
Ariane Utomo, Oki Rahadianto Sutopo \\ University of Melbourne | Youth Studies Centre Fisipol UGM \\ ariane.utomo@unimelb.edu.au | oki.rahadianto@ugm.ac.id
}

\section{ABSTRACT}

An examination into the changing patterns, meaning, norms, and discourses around marriage - in the context of transition to adulthood - offers a unique window to disentangle the complex processes of social change in post -Reformasi Indonesia. Among the many dimensions of social change affecting changing patterns of marriage and transition to adulthood include: globalization; demographic transition; trends in population mobility concerning migration and urbanization; economic uncertainties and inequality; and a series of contestation on norms around marriage and the family which has shadowed the political landscape post-Reformasi. How does such a complex process of social change shape the changing patterns and narratives on marriage? In particular, how do young people navigate the changing marriage patterns in the context of such complex, rapid, and massive social change? These two questions are pivotal to the current special issue in Jurnal Studi Pemuda. To provide context and highlights the contributions of the papers in this issue, this article reviews several dimensions and indicators of marriage and family change in Indonesia, and outlines their relation to the broader contexts of transition to adulthood and social change in the last two decades following Reformasi.

\section{KEYWORDS: Youth | Transition | Marriage | Social Changes | Indonesia}

\section{PENDAHULUAN}

Dalam perspektif transisi pemuda, domain kehidupan seperti pendidikan, kerja, dan perkawinan secara sosiologis dianggap menegaskan posisi sosial seseorang dalam tahapan kehidupannya (Parker and Nilan 2013; Minza 2012; White, Wyn and Robards 2017). Pendidikan, kerja, dan perkawinan menjadi 'peristiwa kehidupan' yang penting bagi kaum muda untuk menuju masa kedewasaan. Secara normatif, pemuda yang berada di domain pendidikan dianggap masih bergantung pada orang tua. Di sisi lain, pemuda yang telah masuk ke domain kerja dianggap lebih mandiri (Nilan, Julian and Germov 2007; Furlong 2012). Sedangkan pada domain perkawinan, seringkali menjadi tahapan yang krusial dimana pemuda dituntut 'harus' mandiri secara finansial maupun psikologis dengan membawa status yang lebih kompleks seperti menjadi 'partner', suami/istri sekaligus orang tua. Transisi pemuda sebagaimana di- jelaskan oleh White, Wyn and Robards (2017) juga tidak berlangsung di ruang hampa namun baik pemuda maupun domain perkawinan selalu terkait dengan aspek struktur dan kultur yang lebih luas, dengan kata lain, transisi pemuda selalu bersifat relasional dan interseksional. Faktor-faktor tersebut antara lain: generasi, kelas sosial, gender, ras dan etnis. Dalam transisi pemuda kontemporer, aspek relasional dan interseksional tersebut juga terkait dengan reproduksi kesenjangan sosial dalam tingkat global (Sutopo 2016).

Dalam konteks Indonesia, di satu sisi, perkawinan memang bukan lagi menjadi suatu penanda mutlak bahwa individu telah bertransisi dari remaja menjadi dewasa. Pertama, seiring dengan waktu, semakin banyak individu yang menunda perkawinan pertamanya jauh setelah mereka mencapai kemandirian finansial dan/atau penanda kedewasaan lain 
nya, seperti merantau, tinggal terpisah dari orang tua, lulus kuliah, dan mempunyai pekerjaan yang mapan (Jones, 2005, 2007). Kedua, seperti yang didapati di negara-negara Global Selatan lainnya (National Research Council, 2005), jumlah perkawinan anak/remaja di Indonesia - terutama yang dilakukan jauh sebelum batas legal usia dewasa juga masih signifikan (Grijns, Horii, Irianto, \& Saptandari 2020; Beta dan Febrianto 2020 dalam edisi khusus ini).

Di sisi lain, perkawinan belum menjadi institusi yang sifatnya opsional bagi banyak kaum muda di Indonesia. Hal ini berbeda dengan tren yang telah lumayan lama nampak di negara Barat dan Asia Timur, dimana kohabitasi (hidup bersama) dan non-marriage banyak didapati (Lesthaeghe 2010; Raymo, Park, Xie, \& Yeung 2015). Walau proporsi penduduk dewasa/dewasa muda yang belum pernah menikah semakin lama semakin naik, secara umum, norma yang menandai perkawinan sebagai momen penting dalam proses transisi pemuda masih bersifat - kurang lebih- universal di Indonesia (lihat Setyonaluri 2020 dan Himawan 2020 dalam edisi khusus ini). Dengan kata lain, perkawinan bukan suatu penanda wajib, namun tetap menjadi penanda kunci transisi kaum muda menuju masa kedewasaan di Indonesia.

Salah satu indikator utama pergeseran pola perkawinan dalam konteks transisi kepemudaan global adalah penundaan perkawinan. Dalam kasus Indonesia, di antara perempuan yang pernah menikah sebelum umur 50, rata-rata umur pada perkawinan pertama (singulate mean age at marriage) meningkat dari 19.3 pada tahun 1971 menjadi 22.3 pada tahun 2010 (United Nations 2013). Untuk laki-laki, rata-rata umur pada pernikahan pertama naik dari 23.8 menjadi 25.7 dalam kurun waktu yang sama. Dalam rentang tahun yang sama, proporsi penduduk perempuan usia 20-24 yang belum pernah menikah naik dari $18.5 \%$ ke $41.2 \%$ (United Nations 2013).

Salah satu faktor utama dibalik tren penundaan perkawinan adalah semakin luasnya akses pendidikan formal untuk laki-laki dan perempuan di Indonesia. Hal ini selaras dengan teori bahwa seiring dengan modernisasi dan pembangunan ekonomi, transisi kepemudaan mengalami suatu fase pemanjangan (protracted transition to adulthood) (Furstenberg 2010; Naafs \& White 2012). Namun, selain indikator yang terpusat kepada umur, ada banyak dimensi penting lain untuk mendalami pergeseran pola perkawinan di Indonesia.

Studi tentang perubahan pola, makna, norma, dan wacana seputar perkawinan dalam konteks transisi kepemudaan menawarkan suatu jendela unik untuk memahami proses dan kompleksitas yang lebih luas terkait perubahan sosial di Indonesia pasca-Reformasi (Utomo 2014). Dalam hal ini, perubahan sosial yang kami maksud mencakup banyak dimensi yang saling berkelindan. Termasuk di antaranya: globalisasi; transisi demografi; tren mobilitas penduduk terkait migrasi urbanisasi; pembangunan ekonomi, perubahan struktur lapangan kerja, dan ketidakpastian serta kesenjangan ekonomi; dan kontestasi norma seputar perkawinan dan keluarga yang dilatarbelakangi oleh lanskap politik pasca-Reformasi itu sendiri.

Bagaimanakah proses perubahan sosial yang amat kompleks, cepat dan masif ini berimbas terhadap pergeseran pola dan wacana seputar perkawinan? Khususnya, bagaimanakah penduduk muda di Indonesia menavigasi pergeseran pola, norma, makna, dan wacana seputar perkawinan dalam konteks perubahan sosial yang rumit dan lebih besar tersebut? Dua pertanyaan ini mendasari edisi khusus Jurnal Studi Pemuda kali ini. Untuk melatarbelakangi kontribusi makalah pilihan dalam edisi khusus ini, artikel ini mengulas beberapa dimensi dan indikator perubahan pola perkawinan di Indonesia, serta membahas kaitannya dengan pola besar transisi pemuda dan perubahan sosial dalam dua dasawarsa terakhir pasca-Reformasi.

Pembahasan kami terbagi menjadi tiga bagian. Kami memulai dengan membahas beberapa indikator kunci yang dapat merangkum pergeseran pola seputar perkawinan dalam konteks transisi kepemudaan di Indonesia. Dalam bagian kedua, kami membahas secara lebih spesifik konteks sosial-politik-ekonomi dibalik pergeseran pola tersebut. Terakhir, kami menjabarkan studi-studi pilihan yang kami sertakan 
dalam edisi khusus ini.

\section{INDIKATOR PERUBAHAN POLA PERKAW- INAN DAN TRANSISI PEMUDA}

Secara umum, pergeseran pola perkawinan dalam konteks transisi kepemudaan di Indonesia tercermin dalam beberapa indikator kunci. Pertama, proporsi penduduk muda yang belum menikah di usia 20an semakin meningkat. Kedua, seiring dengan poin pertama, tren penundaan perkawinan terbaca dari meningkatnya rata-rata umur pada perkawinan pertama. Ketiga, telah terjadi pergeseran pola dalam proses dan praktik pemilihan pasangan dimana kaum muda memiliki lebih banyak agensi untuk menentukan pasangan hidup mereka dibanding generasi terdahulu. Studi terdahulu merangkum faktor-faktor berikut dibalik ketiga tren makro ini: partisipasi kaum muda yang lebih besar dalam pendidikan; urbanisasi, migrasi dan peningkatan mobilitas spasial kaum muda - termasuk semakin besarnya kemungkinan hidup terpisah dari orang tua sebelum menikah karena pekerjaan atau sekolah; perubahan peran gender; perubahan infrastruktur komunikasi dan transportasi; dan peningkatan penggunaan media sosial dan teknologi komunikasi dalam membina hubungan romantis (Kusumaningtyas \& Hakim 2019; Nilan 2008; Smith-Hefner 2005; Utomo, Reimondos, Utomo, McDonald, \& Hull 2016).
Patut dicatat bahwa tren dari waktu ke waktu ketiga indikator di atas sifatnya tidak selalu linear, kadang stagnan atau malah regresif, dan heterogen dari satu kelompok masyarakat ke kelompok lainnya.

\section{Prevalensi perkawinan}

Tabel 1 menampilkan persentase penduduk muda - dalam kisaran umur 5 tahunan antara 20 34 - yang sudah pernah menikah (ever married) di Indonesia dari tahun 2000 - 2010. Pada umumnya, dalam setiap kelompok umur persentase perempuan yang sudah pernah menikah lebih besar jumlahnya daripada laki-laki di kelompok umur yang sama. Semakin lama, persentase perempuan yang sudah pernah menikah di setiap kelompok umur semakin berkurang. Misalnya, pada tahun 1975, 97.8\% perempuan muda dewasa di kelompok umur 30-34 sudah pernah menikah. Sementara itu, menurut catatan Sensus Penduduk tahun 2010, kurang dari 90 persen perempuan dalam kategori umur tersebut berstatus sudah pernah menikah. Berarti, sekitar 10 persen perempuan yang usia 30-34 belum pernah menikah. Patut dicatat bahwa angka 10 persen ini merujuk kepada sekitar 590, 595 perempuan. Pada saat penulisan artikel ini, hasil dari Sensus Penduduk 2020 masih belum selesai. Namun berdasarkan tren yang sudah ada, baik persentase dan jumlah penduduk dewasa muda berumur 30-34

\section{Tabel 1:}

Persentase Penduduk Muda Berumur 20-34 yang Sudah Pernah Menikah di Indonesia, 1971-2010

\begin{tabular}{ccccccccccc}
\hline $\begin{array}{c}\text { Kelompok } \\
\text { Umur }\end{array}$ & \multicolumn{2}{c}{$\mathbf{1 9 7 1}$} & \multicolumn{2}{c}{$\mathbf{1 9 8 0}$} & \multicolumn{2}{c}{$\mathbf{1 9 9 0}$} & \multicolumn{2}{c}{$\mathbf{2 0 0 0}$} & \multicolumn{2}{c}{$\mathbf{2 0 1 0}$} \\
& $\mathbf{L}$ & $\mathbf{P}$ & $\mathbf{L}$ & $\mathbf{P}$ & $\mathbf{L}$ & $\mathbf{P}$ & $\mathbf{L}$ & $\mathbf{P}$ & $\mathbf{L}$ & $\mathbf{P}$ \\
\hline $20-24$ & 41.4 & 81.5 & 40.6 & 77.7 & 28.3 & 64.3 & 25.8 & 56.9 & 30.9 & 60.8 \\
$25-29$ & 81.5 & 95.1 & 80.5 & 92.6 & 71.0 & 88.8 & 65.7 & 83.3 & 65.1 & 88.3 \\
$30-34$ & 93.9 & 97.8 & 94.0 & 96.6 & 90.6 & 95.6 & 88.2 & 93.1 & 87.2 & 89.4 \\
\hline
\end{tabular}

Sumber data: UN World Marriage Data berdasarkan Sensus Penduduk Indonesia. Sensus 1971 tidak mencakup Papua/Papua Barat. United Nations, Department of Economic and Social Affairs, Population Division (2017). World Marriage Data 2017 (POP/DB/Marr/Rev2017).

Ket:

$\mathrm{P}:$ Perempuan

L : Laki-laki 
tahun yang belum menikah akan terus bertambah.

Dengan indikator di atas, apakah kita dapat menyimpulkan bahwa perkawinan adalah norma sosial yang sifatnya masih universal di Indonesia? Seberapa umumkah kaum muda di Indonesia berekspektasi dan diekspektasikan untuk "menikah" dalam transisi mereka menuju ke masa kedewasaan? Apakah perkawinan tetap menjadi satu-satunya institusi keluarga yang diterima masyarakat? Bagaimana dengan alternatif bentuk keluarga atau lifestyle lainnya seperti kohabitasi atau non-marriage?

Secara teoritis, Beck and Beck-Gernsheim (1995) menjelaskan dampak dari societalization adalah pemuda harus menciptakan narasi biografi-nya sendiri (DIY Biography) termasuk terkait dengan pilihan alternatif bentuk keluarga. Hal ini bukan berarti pemuda bebas memilih namun justru dihadapkan dengan struktur dan kultur 'lama' yang masih melekat dalam kehidupan sehari-hari. Misalnya mengenai stigma hubungan seksual di luar ikatan perkawinan masih terlihat kuat di Indonesia. Hasil survei World Value Survey di tahun 20172020 menunjukkan bahwa 76.5\% responden di Indonesia mengatakan hubungan sex sebelum menikah "tidak pernah bisa dibenarkan". Kecenderungan ini menunjukkan dua sisi carut marut antara kontradiksi sistemik dan ambivalensi 'life world' sebagai akibat dari refleksivitas yang menyerang balik formasi tatanan dalam era modernitas lanjut (Beck 2014). Sementara itu, di Jepang - untuk pembanding hanya 5.6\% responden memberikan respon yang sama. Dalam survei yang sama, 70.1\% responden Indonesia menyatakan tidak suka jika hidup bertetangga dengan pasangan yang hidup bersama/tidak menikah. Di sini, persentase responden berumur di bawah 30 tahun dengan respon "tidak suka" (65.1\%) lebih sedikit daripada persentase berumur berumur 50 tahun ke atas (73.6\%) (Inglehart et al. 2020).

\section{Unsur Temporal: Umur Memasuki Perkawinan}

Dalam kajian ilmu kependudukan, rata-rata umur perempuan pada perkawinan pertama adalah sebuah indikator penting untuk memahami tren angka kelahiran dan pertumbuhan penduduk. Pada umumnya, karena perkawinan masih dianggap sebagai institusi tunggal untuk mempunyai anak di Indonesia, semakin muda seorang perempuan menikah, semakin panjanglah durasi/jangka waktu yang dialaminya untuk berkesempatan hamil dan melahirkan. Dengan kata lain, ada korelasi negatif antara umur pada perkawinan pertama dan jumlah anak

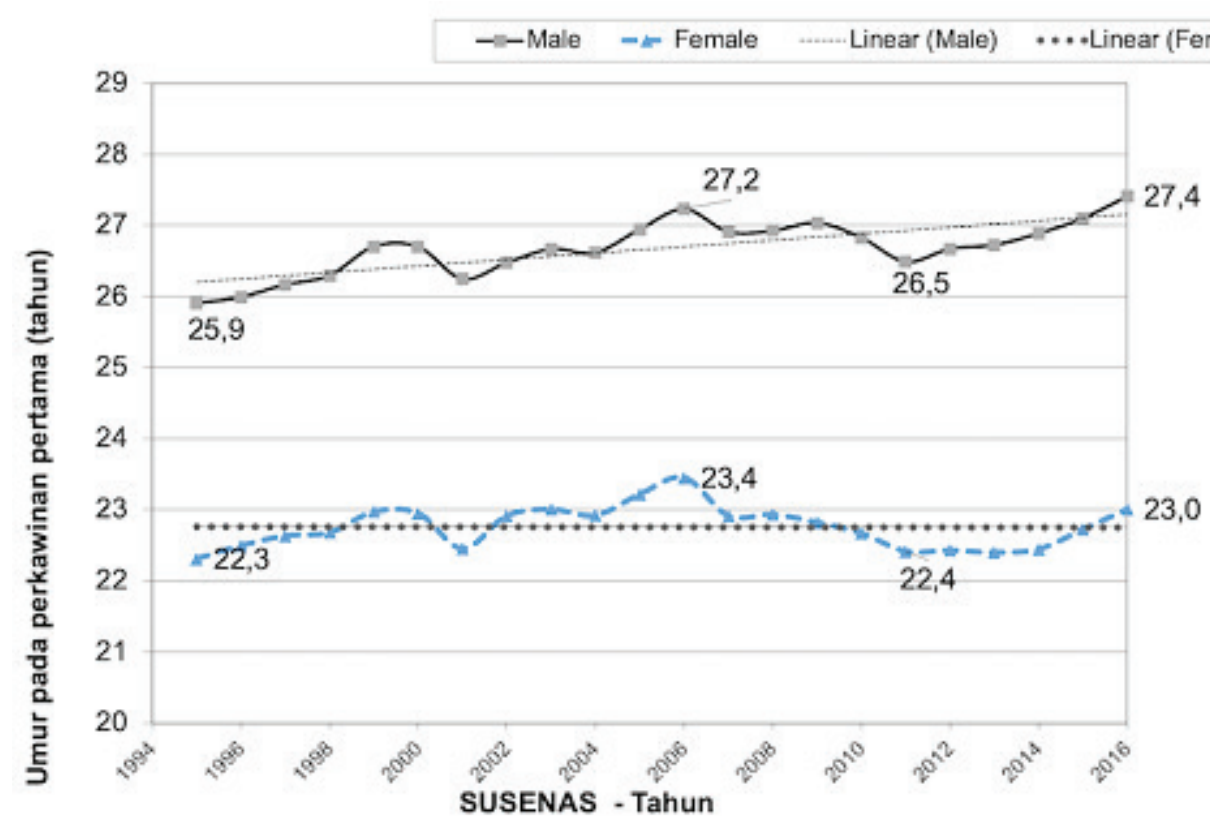

Figure 1:

Singulate Mean Age at Marriage, Susenas

Sumber: diadaptasi dari Hull dan Hartanto, 2018. Singulate mean age at marriage: rata-rata lama hidup membujang yang dinyatakan dalam tahun di antara mereka yang menikah sebelum usia 50 tahun. 
yang dilahirkan.

Meskipun ekspektasi sebelumnya adalah peningkatan akses perempuan ke pendidikan dan lapangan kerja akan mempertahankan tren peningkatan umur pada perkawinan pertama, data-data terbaru menunjukkan beberapa nuansa yang tidak diantisipasi sebelumnya. Misalnya, Hull dan Hartanto (2018) menemukan bahwa sejak pertengahan tahun 2000-an, telah terjadi stagnasi, atau regresi tren usia perkawinan pertama. Angka rata-rata usia perkawinan pertama untuk perempuan di awal 90-an adalah sekitar 22. Angka tersebut naik menjadi 23.2 pada tahun 2006, tetapi turun menjadi 22,4 pada tahun 2011-2013, untuk kemudian meningkat lagi di tahun 2015 (Hull \& Hartanto 2018). Ada spekulasi yang mengaitkan penurunan usia pernikahan pertama sebagai refleksi dari perdebatan dan ketegangan seputar nilai-nilai keluarga dan moralitas antara kelompok konservatif etnis-agama dan kekuatan progresif di era pasca-reformasi (Hull \& Hartanto 2018).

\section{Menuju Perkawinan: Pacaran dan Memilih 'Jodoh'}

Dalam kajian kepemudaan global, perspektif generasi terutama dari Karl Mannheim (1952) dimunculkan kembali dan direvisi guna melakukan kritik terhadap pendekatan transisi yang cenderung melihat perkembangan pemuda secara linear, deterministik dan fixed. Sebaliknya, menurut Woodman and Wyn (2015a), penting untuk mengetahui mengenai lokasi (site), secara sederhana, dalam konteks sosio historis seperti apa generasi baru dapat muncul. Lokasi dan konteks sosio historis ini akan membentuk subjektivitas pemuda, namun tidak secara mekanistis. Dengan kata lain, kaum muda sangat mungkin merespon perubahan sosial dengan cara 'baru' yang relatif berbeda dari generasi sebelumnya. Perspektif generasi sosial memungkinkan youth studies scholars untuk tidak terjebak pada dimensi kontinuitas dan reproduksi sosial namun juga menggarisbawahi mengenai pentingnya dimensi perubahan (France and Roberts 2015; Woodman and Wyn 2015b), tidak terkecuali dalam transisi pemuda menuju domain pernikahan.
Dalam konteks Indonesia, selain pergeseran tren prevalensi penundaan perkawinan, proses menuju perkawinan yang dihadapi oleh kaum muda juga berubah seiring dengan waktu dan perubahan antar generasi. Dibandingkan dengan generasi-generasi terdahulu, kaum muda kontemporer memiliki lebih banyak agensi untuk memilih suami/istri mereka (Nilan 2008; Robinson 2015; Utomo, Reimondos, Utomo, McDonald, \& Hull 2016). Peran pihak ketiga - orang tua, kerabat, institusi adat, otoritas agama, dan negara, walau masih relevan - telah melemah dalam proses pemilihan pasangan. Di sini, kami merujuk kepada studi yang menggunakan data Survei Transisi ke Dewasa Jakarta 2010 di Jabodetabek (Utomo et al. 2016). Meskipun hanya 4\% dari responden yang sudah menikah yang menyatakan bahwa perkawinan mereka diatur oleh orang lain, lebih dari sebagian responden melaporkan bahwa orang tua atau mertua mereka memainkan peran utama dalam keputusan perkawinan mereka. Terlepas dari keterlibatan orang tua dalam pengambilan keputusan pernikahan secara terus menerus, terdapat indikasi praktik yang semakin diterima untuk meminta otoritas agama yang dihormati dan dipercaya untuk menjadi pencari jodoh (misalnya, ta'aruf, lihat Supratman \& Mardianti 2016; Khoiron \& Eliyanah 2020). Selain itu, dari waktu ke waktu, perbedaan umur suami-istri semakin mengecil (Utomo 2014), proporsi perempuan yang menikah dengan laki-laki berpendidikan (sedikit) lebih rendah meningkat (Utomo 2014), dan perkawinan antar suku semakin lumrah terjadi di antara kaum muda yang tinggal di kota besar (Utomo \& McDonald 2016).

\section{PERUBAHAN POLA PERKAWINAN DAN TRANSISI PEMUDA PASCA-REFORMASI}

Pasca-Reformasi, kita menyaksikan semakin maraknya kontestasi narasi dan ideologi antara berbagai kekuatan politik dan sipil di Indonesia. Meskipun kontestasi ini sebagian besar bersifat politis, namun sebagian besar manifestasinya terungkap pula melalui perdebatan tentang norma peran gender, perkawinan, dan nilai-nilai seputar keluarga. Perdebatan-perdebatan ini bukanlah hal baru, justru 
telah berlangsung cukup lama, bahkan sebelum Reformasi. Tetapi, seiring dengan konsolidasi berbagai kekuatan demokrasi sejak 1998, perdebatan ini menjadi lebih terdengar jelas.

Salah satu contoh kontestasi yang kami maksud adalah perdebatan seputar usia minimum perkawinan. Setelah melalui proses hukum yang cukup panjang, akhirnya DPR mengesahkan revisi UU Perkawinan dan mengubah batas minimal menikah untuk laki-laki dan perempuan. Sebelumnya, batas usia minimal menikah bagi laki-laki adalah 19 tahun dan perempuan 16 tahun. Revisi UU Perkawinan menerapkan batas minimal umur yang sama untuk laki-laki dan perempuan di usia 19 tahun. Revisi batas usia minimal perkawinan ini dapat dibilang mewakili aspirasi kelompok masyarakat yang menyuarakan nilai-nilai progresif. Di sisi lain, reformasi juga menghasilkan draf KUHP yang kontroversial - yang mencakup proposal untuk melarang seks di luar nikah.

Contoh lain berkaitan dengan soal relasi gender dalam transisi perkawinan kaum muda. Seperti diulas di atas, perluasan kesempatan sekolah dan bekerja perempuan tercermin - antara lain - pada rata-rata usia yang lebih tua pada pernikahan pertama, ukuran keluarga yang lebih kecil, dan semakin kecilnya perbedaan umur antara suami istri. Di satu sisi, tren-tren tersebut secara relatif menawarkan prospek yang penuh harapan untuk hubungan gender yang lebih egaliter, tidak hanya dalam perkawinan tetapi juga untuk masyarakat yang lebih luas. Namun perkembangan terbaru menunjukkan bahwa relasi gender pasca-reformasi justru mengalami banyak ketidakpastian (Afrianty 2019; Utomo 2016). Pengesahan RUU anti-kekerasan seksual yang terhenti merupakan indikasi perdebatan ideologis antara kekuatan konservatif di satu sisi, dan kekuatan yang lebih progresif yang mendorong agenda berbasis hak bagi perempuan dan minoritas di sisi lain (Afrianty 2019).

Contoh-contoh ini menunjukkan bagaimana institusi perkawinan dan keluarga telah menjadi menjadi medan pertempuran yang semakin penting antara kekuatan konservatif yang mempromosikan wacana seperti gerakan Indonesia tanpa pacaran dan poligami di satu sisi, dan kekuatan yang lebih progresif di sisi lain. Dibaca dengan perspektif Bourdieusian maka dapat dijelaskan bahwa siapa yang menang dalam pertarungan antara doxa dengan heterodoxa (Myles 2004) ini akan menentukan kehidupan dan tatanan sosial seperti apa yang akan terjadi di Indonesia pada masa depan. Perubahan pola dalam prevalensi, waktu, dan sifat perkawinan menyoroti ketegangan yang mendasari, kontradiksi, dan akomodasi di berbagai spektrum agenda ideologis terkait tempat dan peran perempuan dan laki-laki muda Indonesia, baik di dalam maupun di luar institusi perkawinan.

\section{Ekonomi}

Secara teoritis, Ulrich Beck (1992) dalam bukunya Risk Society: Towards a New Modernity menjelaskan bahwa individu semakin lama semakin terjebak pada risiko baru yang timbul sebagai dampak dari kemajuan yang diciptakan oleh manusia itu sendiri. Kata kunci dalam memahami pemikiran Beck (1992) adalah konsepnya mengenai risiko dan individualisasi. Dalam era modernitas lanjut, individu semakin lama harus menanggung risiko yang semakin besar dan semakin tidak dapat diprediksi dampaknya di masa depan. Usaha individu untuk mengatasi risiko pun juga akan menciptakan risiko yang baru. Dalam prosesnya, risiko semakin ditanggung oleh individu, dengan kata lain semakin terindividualisasi, namun sebaliknya, risiko juga semakin terproduksi secara global. Individu harus semakin refleksif supaya dapat bertahan dalam kondisi yang serba tidak pasti. Dengan semakin refleksif maka diharapkan individu dapat mengatasi risiko-risiko yang senantiasa mengancam dirinya baik di masa sekarang maupun di masa depan, salah satunya terkait aspek ekonomi dalam transisi pemuda menuju domain pernikahan.

Studi Nilan (2008) menunjukkan bahwa dalam konteks pemuda Indonesia tahapan pernikahan masih didominasi pada tiga hal, yaitu: faith, family, dan finances. Keyakinan dan keluarga berkaitan dengan trajektori kualitas dalam kehidupan pernikahan. Hal ini menyangkut pada pertimbangan-pertimbangan nilai dari keyakinan dan tradisi 
atau standar keluarga. Sedangkan, finances mengarah pada de-traditionalisation yang menyangkut isu ekonomi dan pekerjaan. Beck (1992) menegaskan bahwa penekanan pada hubungan finances di sebuah pernikahan mengindikasikan potensi marriage partner melalui bentuk 'market relations'. Pada bentuk ini memungkinkan terciptanya pembagian-pembagian yang berdasar pada demand and supply dari standar kriteria setiap individu. Kemunculan Tinder, sebuah aplikasi dating, menjadi salah satu contoh platform dari apa yang Beck sebut sebagai 'market relations'. Hal ini menunjukkan bagaimana risiko dalam bentuk 'market relations' yang tereproduksi secara sistemik di berbagai level justru harus diselesaikan oleh pemuda itu sendirisayangnya, dengan kondisi awal dimana posisi mereka tidak dimulai dari start yang sama dan distribusi kapital juga tidak merata di kalangan kaum muda sebagai 'petarung' dalam pasar perkawinan tersebut. Dengan kata lain, pergeseran logic pernikahan menjadi 'market relations' berpotensi tidak hanya untuk melanggengkan reproduksi sosial namun juga dalam taraf yang ekstrem dimungkinkan memperlebar kesenjangan sosial dalam masyarakat.

Nilan (2008) dalam studinya juga menunjukkan beberapa perubahan terutama dalam konteks pemuda urban. Dimensi usia misalnya, 37 persen perempuan menikah di usia 15-19 tahun di tahun 1971, di tahun 2003 hanya tersisa 10 persen saja perempuan yang memilih untuk menikah di usia tersebut. Faktor eksternal seperti pengaruh media, meningkatnya gaya hidup perkotaan, dan perubahan kebijakan dari setiap rezim pemerintah menjadi terms yang mewarnai perubahan-perubahan pemuda dalam mengimajinasikan sebuah pernikahan. Dengan mensintesakan antara perspektif generasi sosial (Mannheim 1952; Sutopo 2014; Woodman and Wyn 2015a) dan individualisasi (Beck 1992; Beck and Beck-Gernsheim 1995), fenomena ini dapat dibaca sebagai manifestasi keterkaitan yang bersifat kontradiktif antara dimensi perubahan sosial dan societalization dengan refleksivitas sebagai hasil dari praktik pemaknaan subjektif kaum muda. Pada satu titik, refleksivitas yang termanifestasi sebagai strategi emansipasi dapat berhasil untuk menegosiasikan dengan hambatan struktural di berbagai level.
Namun hambatan tersebut mempunyai karakter yang berlapis dan bertingkat sehingga kaum muda harus terus menerus melakukan negosiasi di berbagai tahap kehidupannya, baik itu sebelum, pada saat maupun setelah bertransisi menuju domain pernikahan. Menjadi refleksif dan mempunyai stok refleksivitas sebagai kapital budaya yang melimpah hanya menjadi titik masuk saja dalam mengurai benang kusut risiko yang akan terus menerus muncul, dengan kata lain, kaum muda membutuhkan kapital-kapital yang lain untuk menegosiasikan berbagai aspek dalam kehidupannya. Takdir 'manusia' dalam era modernitas lanjut adalah selalu dihadapkan pada risiko yang tidak pernah habis. Tidak ada pilihan lain bagi kaum muda selain harus berani berselancar mengarungi gelombang besar risiko yang tidak dapat terprediksi tersebut, jika tidak siap berselancar maka bersiaplah tenggelam di dasar lautan risiko yang terdalam.

\section{PENGANTAR EDISI KHUSUS}

Artikel-artikel yang tersaji dalam edisi khusus Jurnal Studi Pemuda kali ini memotret kekompleksitasan dan keberagaman transisi kaum muda menuju dunia perkawinan dalam konteks yang berubah di Indonesia. Para kontributor tidak hanya menggunakan cara pandang yang bervariasi dari berbagai kajian interdisipliner seperti kajian kepemudaan, kajian budaya, demografi dan sosiologi, namun juga terkait dengan metode dan titik masuk kajian. Studi Himawan (2020) misalnya menggunakan mixed methods untuk memahami keterkaitan antara agama, status lajang dan kebahagiaan, sedangkan Setyonaluri dkk (2020) menggunakan data survey SUSENAS dalam menjelaskan keterkaitan antara tingkat pendidikan dan pilihan melajang. Di sisi lain, Beta dan Febrianto (2020) dalam edisi khusus ini menggunakan discourse tracing sebagai metode analisa dalam memahami produksi wacana mengenai perempuan muda, Choiron dan Elinayah (2020) menawarkan metode analisis isi dan Putri dkk (2020) menggunakan narasi biografi untuk menunjukkan pluralitas pemaknaan subjektif generasi kontemporer. Kekayaan dalam edisi khusus ini juga ditunjukkan melalui titik masuk yang bervariasi tidak hanya melalui pemuda namun juga remaja awal dan dewasa 
serta film. Dibawah ini kami mengantarkan secara singkat enam artikel dan satu review buku yang termuat dalam edisi khusus Jurnal Studi Pemuda kali ini.

Putri, Fahadi, Kusumaningtyas, Utomo dan Sutopo (2020) dalam studinya mengeksplorasi narasi biografi transisi perempuan muda menuju dunia pernikahan di Gunung Kidul dan Yogyakarta dalam konteks perubahan sosial yang pesat dan masif. Dengan menggunakan perspektif generasi sosial, mereka menyoroti tidak hanya konteks transisi menuju pernikahan yang telah berubah namun juga pluralitas pemaknaan subjektif perempuan muda sebagai representasi generasi kontemporer di Indonesia. Cara pandang post-feminisme dan pilihan perempuan digunakan untuk menunjukkan terjadinya kontradiksi dalam dunia nyata terkait dengan posisi perempuan muda dalam menjalani transisi menuju dunia pernikahan. Di sisi lain, proses pencarian pasangan ideal masih diwarnai dengan imajinasi mengenai term seperti saleh, bertanggung jawab dan mapan. Namun, hal ini bukan berarti perempuan muda mendambakan hubungan pernikahan yang konservatif, justru negosiasi yang dilakukan merupakan manifestasi strategi refleksif dalam menghadapi perubahan sosial yang cepat dan massif tersebut. Temuan mereka menunjukkan kontradiksi dan ambivalensi antara pilihan individu dan masih kuatnya nilai-nilai keluarga dan lingkungan sosial sekitarnya dalam transisi perempuan muda menuju dunia pernikahan. Dalam artikel kedua, Choiron dan Elinayah (2020) menggunakan titik masuk budaya populer terutama film percintaan untuk mengeksplorasi tentang representasi pernikahan ideal. Dengan kata lain, siapa menikah dengan siapa? Siapa tidak (boleh) menikah dengan siapa? Dan aspek apa saja yang direpresentasikan dalam film percintaan mengenai pernikahan ideal tersebut. Choiron dan Elinayah secara spesifik mengeksplorasi lebih lanjut mengenai seberapa jauh aspek agama dan kelas sosial dianggap penting dalam menentukan siapa menikah dengan siapa dalam film percintaan tersebut. Secara detail, Choiron dan Elinayah juga menunjukkan bagaimana kecenderungan tersebut tidak dapat dilepaskan dari islamisasi di era pasca-reformasi, meningkatnya per tumbuhan ekonomi baik skala makro maupun mikro pasca krisis keuangan global dan promosi agenda kesetaraan gender.

Dengan menggunakan titik masuk serta subjek yang berbeda, artikel ketiga dari Himawan menjelaskan mengenai peran agama dalam konstruksi makna mengenai pengalaman melajang di Indonesia; sedangkan dalam artikel keempat, Setyonaluri, Maghfirah dan Aryaputra (2020) mengeksplorasi mengenai peran pendidikan bagi keputusan untuk melajang di antara para orang dewasa. Himawan dengan menggunakan mixed methods menemukan bahwa peran agama masih penting dalam mengkonstruksi pengalaman melajang, hal ini secara spesifik termanifestasi dalam tiga aspek antara lain: lajang sebagai masa 'pra-nikah' yang dikehendaki Tuhan, masa untuk berkarya di luar lingkup rumah tangga, dan masa di mana norma sosial dan agama konservatif dikompromikan dengan perkembangan nilai budaya. Di sisi lain, dengan menggunakan analisis multivariat, Himawan menemukan bahwa diantara para lajang, agama dapat meningkatkan kepuasan hidup namun tidak menjadi obat mujarab untuk mengurangi kesepian. Dalam artikel selanjutnya, Setyonaluri, Maghfirah dan Aryaputra tidak melihat peran agama dalam pemaknaan melajang namun justru mengeksplorasi lebih jauh mengenai tingkat pendidikan. Dengan menggunakan data SUSENAS tahun 2007 dan 2017, mereka menemukan bahwa tambahan tahun pendidikan mengurangi probabilitas tidak menikah namun hanya sampai tingkat Sekolah Menengah Atas (SMA). Namun setelah SMA, tambahan pendidikan akan meningkatkan probabilitas tidak menikah. Hal ini menunjukkan bagaimana dalam konteks Indonesia, norma tradisional terkait peran gender masih kuat. Lebih lanjut, mereka juga menemukan bahwa laki-laki dan perempuan berpendidikan tinggi memiliki kecenderungan yang sama untuk tidak menikah di Indonesia.

Dalam artikel kelima, Colquhoun dan Nilan (2020) menggunakan narasi dari enam remaja pria dari suku Sasak Lombok untuk mengeksplorasi mengenai masih kuatnya fenomena menikah muda di daerah tersebut. Tradisi dan praktik keagamaan, norma-norma gender dalam konteks percintaan dan perilaku seksual, serta proses 'penormalan' transisi me- 
nuju pernikahan secara lebih awal sebagai manifestasi implisit reproduksi spiral kemiskinan menjadi faktor-faktor yang saling berpengaruh bagi terjadinya fenomena tersebut. Bagi remaja pria di Lombok, keterlambatan dalam memutuskan untuk menikah misalnya, akan membuat mereka kehilangan kesempatan dan sekaligus merelakan calon yang dicintainya dinikahi pemuda lain. Di sisi lain, secara simbolik, penyematan nilai maskulin yang tinggi terkait dengan status menjadi suami dan ayah meskipun di usia muda menjadi salah satu aspek penting yang mereka bahas dalam artikel tersebut. Lebih lanjut, kondisi kemiskinan dan marginalisasi menjadi konteks dimana menikah muda justru merupakan manifestasi dari strategi kompensasi. Dari sini, Colquhoun dan Nilan mengeksplorasi lebih jauh mengenai hegemoni maskulinitas sekaligus mengabstraksikan fenomena menikah muda sebagai bagian dari reproduksi kemiskinan secara intergenerasional yang terjadi di Lombok utara. Dengan titik masuk dan pendekatan yang berbeda, Beta dan Febrianto (2020) dalam artikel keenam melakukan eksplorasi secara kritis terkait produksi wacana yang dilakukan oleh organisasi internasional mengenai pernikahan anak terutama perempuan di Indonesia sebagai bagian dari Global South. Beta dan Febrianto mempertanyakan mengapa perempuan muda selalu ditempatkan sebagai subjek yang rapuh dan sebagai korban. Meskipun mereka menyadari mengenai potensi bahaya dan kekerasan dalam praktik menikah muda, namun narasi-narasi yang direproduksi oleh organisasi internasional cenderung bersifat monolitik dan mereduksi kompleksitas serta diversitas yang terjadi di lapangan. Secara spesifik, narasi-narasi yang direproduksi seringkali terjebak pada penyalahan terhadap tradisi komunitas, keterbelakangan dan kesenjangan gender. Bagi mereka, wacana dari organisasi internasional cenderung bersifat ahistoris dan universal sehingga tidak menangkap kekompleksitasan fenomena tersebut dan seringkali melupakan unsur agensi dari perempuan muda tersebut.

Edisi khusus dalam Jurnal Studi Pemuda ini ditutup dengan review kritis dari Nurrizky (2020) terhadap buku yang ditulis oleh Nancy-Smith Hefner, seorang antropolog perempuan dari Ame- rika yang berjudul 'Islamizing Intimacies: Youth, Sexuality, and Gender in Contemporary Indonesia' terbit tahun 2019. Menurut Nurrizky, buku ini menarik tidak hanya karena pembacaannya yang dalam dan spesifik. Namun juga karena sekaligus menghadirkan narasi yang luas dan mendetail. Pemaparan konteks yang dirangkai dengan narasi deskriptif secara etnografis mampu memberikan gambaran yang teliti terhadap perubahan sosial dalam masyarakat, dan korelasinya terhadap realitas kaum muda sebagai muslim sekaligus representasi generasi muda kontemporer di Indonesia.

Artikel-artikel mengenai transisi pemuda menuju dunia pernikahan yang telah kami uraikan diatas tidak hanya merefleksikan kekompleksitasan dan keberagaman isu yang coba kami tawarkan dalam edisi khusus Jurnal Studi Pemuda ini, namun sebagai editor kami juga melihat pentingnya membuka, melanjutkan dan mengembangkan dialog di antara para intelektual dari berbagai macam disiplin ilmu tidak hanya di Indonesia namun juga dengan intelektual dari mancanegara. Menurut kami, dialog keilmuan baik dalam level lokal, nasional dan global ini penting untuk mewujudkan apa yang dinamakan sebagai plurality of voices (Connell 2007) khususnya dalam kajian kepemudaan di Indonesia ( $\mathrm{Su}-$ topo 2016) serta untuk meneruskan dan mempertahankan spirit demokratisasi produksi pengetahuan dalam payung besar ilmu-ilmu sosial.

\section{DAFTAR PUSTAKA}

Afrianty, Dina. 2020. "Rising Public Piety and The Status of Women in Indonesia Two Decades After Reformasi". TRaNS: Trans-Regional and - National Studies of Southeast Asia, Vol 8 (1), 65-80.

Beck, U. 1992. Risk Society: Towards a New Modernity. London: Sage.

Beck, U and Beck-Gernsheim, E. 1995. The Normal Chaos of Love. London: Wiley Publishing. 
Beck. U. 2014. Ulich Beck: Pioneer in Cosmopolitan Sociology and Risk Society. Singapore: Springer.

Beta, Annisa. R, dan Ryan Febrianto. 2020. "Are Indonesian Girls Okay? An Examination Of The Discourse Of Child Marriage, Victimization, And Humanitarian Visuality Of Global SouthGirls". Jurnal Studi Pemuda, Vol 9 (2). doi: 10.22146/studipemudaugm.57432

Choiron, Nabhan F., dan Evi Eliyanah. 2020. "Who Marries Whom On Silver Screen? Religion And Social Class In Marriage Patterns In Contemporary Indonesian Films". Jurnal Studi Pemuda, Vol 9 (2). doi: 10.22146/studipemudaugm.58075

Connell, R. 2007. Southern Theory: The Global Dynamics of Knowledge in Social Science. Cambridge: Polity Press.

Colquhoun, Lisa., dan Pamela Nilan. 2020. "Early Marriage among Sasak Boys in Rural NorthLombok". Jurnal Studi Pemuda, Vol 9 (2). doi: 10.22146/studipemudaugm.56370

France, A and S. Roberts. 2015. "The Problem of Social Generations: A Critique of the New Emerging Orthodoxy in Youth Studies". Journal of Youth Studies 18(2): 215-230.

Furlong, A. 2012. Youth Studies: An Introduction. London: Routledge.

Furstenberg, F. F. 2010. "On a New Schedule: Transitions to Adulthood and Family Change". The Future of Children, 20(1), 67-87.

Grijns, M., Horii, H., Irianto, S., \& Saptandari, P. (Eds.). 2020. Marrying Young in Indonesia: Voices, Laws and Practices. Singapore: ISEAS Publishing.

Himawan, Karel K. 2020. "Menikah adalah Ibadah: Peran Agama dalam Merekonstruksi Pengalaman Melajang di Indonesia”. Jurnal Studi Pemuda, Vol 9 (2). doi: 10.22146/studipemudaugm.56548

Hull, T. H., \& Hartanto, W. 2018. How Demographers Reduce Fertility in Indonesia. Paper presented at the Paper presented at the Southeast Asia Biennial Conference on Population and Health in Malang, November 8-9. Ports-
mouth-Brawijaya Centre for Global Health, Population and Policy, Universitas Brawijaya, Malang, Indonesia.

Inglehart, R. et al. 2020. "World Values Survey: Round Seven - Country-Pooled Datafile Version. from JD Systems Institute". Di akses melalui http://www.worldvaluessurvey.org/ WVSContents.jsp

Jones, G. W. 2005. "The "Flight From Marriage" in South-East and East Asia". Journal of Comparative Family Studies, 36(1), 93-119. doi:10.3138/jcfs.36.1.93

Jones, G. W. 2007. "Delayed Marriage and Very Low Fertility in Pacific Asia". Population and Development Review, 33(3), 453-478. doi:10.1111/j.1728-4457.2007.00180.x

Kusumaningtyas, A. P., \& A. I. Hakim. 2019. "Jodoh di Ujung Jempol: Tinder sebagai Ruang Jejaring Baru". Simulacra, 2(2), 101-114.

Lesthaeghe, R. 2010. "The Unfolding Story of the Second Demographic Transition”. Population and Development Review, 36(2), 211-251. doi:10.1111/j.1728-4457.2010.00328.x

Mannheim, K. 1952. Essays on the Sociology of Knowledge. London: Routledge.

Minza, W.M. 2012. "Migran Muda dan Transisi dari Pendidikan ke Dunia Kerja di Pontianak, Kalimantan Barat". Jurnal Studi Pemuda 1(2): 153-164.

Myles, J.F. 2004. "From Doxa to Experience: Issues in Bourdieu's Adoption of Husserlian Phenomenology". Theory, Culture \& Society 21(2): 91-107.

Naafs, S., \& Ben White. 2012. "Generasi Antara: Refleksi tentang Studi Pemuda Indonesia”. Jurnal Studi Pemuda, 1(2), 89-106.

National Research Council, C. o. P. 2005. Growing up Global: The Changing Transitions to Adulthood in Developing Countries: National Academies Press.

Nilan, P. 2008. "Youth transitions to urban, middle-class marriage in Indonesia: faith, family and finances". Journal of Youth Studies, 11(1), 65-82. doi:10.1080/13676260701690402 
Nilan, P, Julian R and Germov, J. 2007. Australian Youth: Social and Cultural Issues. Australia: Pearson Education.

Nurrizky, Arya Malik. 2020. "Book Review: Romansa dan Religi: Ambivalensi Pemuda Muslim Kontemporer". Jurnal Studi Pemuda, Vol 9 (2).

Parker, Lyn, and Pam Nilan. 2013. Adolescents in Contemporary Indonesia. London: Routledge.

Putri, Rani Dwi., Prasakti Ramadhana Fahadi., Amelinda Pandu Kusumaningtyas, Ariane Utomo, dan Oki Rahadianto Sutopo. 2020. "Navigating the Future Husband: Perempuan Muda, Negosiasi Pernikahan dan Perubahan Sosial”. Jurnal Studi Pemuda Vol 9 (2). doi:10.22146/studipemudaugm.57996

Raymo, J. M., Park, H., Xie, Y., \& Yeung, W.-j. J. 2015. "Marriage and Family in East Asia: Continuity and Change". Annual Review of Sociology, 41(1), 471-492. doi:10.1146/annurev-soc-073014-112428.

Setyonaluri, Diahhadi., Aidah Maghfirah., dan Calvin Aryaputra. 2020. "Norms in transition? The Relationship between Education and Singlehood". Jurnal Studi Pemuda, Vol 9 (2). doi:10.22146/studipemudaugm.57995

Smith-Hefner, N. J. 2005. "The New Muslim Romance: Changing Patterns of Courtship and Marriage among Educated Javanese Youth". Journal of Southeast Asian Studies, 36(3), 441-459. doi:10.1017/ S002246340500024X

Smith-Hefner, Nancy J. 2019. Islamizing Intimacies: Youth, Sexuality and Gender Contemporary Indonesia. USA: University of Hawai'i.

Supratman, L. P., \& P Mardianti. 2016. "Komunikasi interpersonal pasangan suami istri melalui taaruf online dating". Jurnal Penelitian Komunikasi, 19(2), 165-178.

Sutopo, O.R. 2014. "Perspektif Generasi dalam Kajian Kepemudaan" in Azca, M. Najib, Derajad S. Widhyharto \& Oki Rahadianto Sutopo (Eds). Buku Panduan Studi Kepemudaan: Teori, Metodologi dan Isu-Isu Kontemporer. Yogyakarta: Youth Studies Centre Fisipol UGM.
Sutopo, O.R. 2016. "Agenda Pengembangan Kajian Kepemudaan di Indonesia”. Jurnal Sosiologi Pendidikan Humanis 1(2): 161-172.

United Nations, U., Population Division. 2013. "World Marriage Data 2012 (POP/DB/Marr/ Rev2012)". Diakses melalui http://data.un.org/ DocumentData.aspx?id=321

Utomo, Ariane. 2014. "Marrying Up? Trends in Age and Education Gaps Among Married Couples in Indonesia." Journal of Family Issues 35(12):1683-1706.

Utomo, Ariane. 2016. "Gender in the Midst of Reforms: Attitudes to Work and Family Roles among University Students in Urban Indonesia”. Marriage \& Family Review, 52(5), 421441. doi:10.1080/01494929.2015.1113224

Utomo, Ariane, Anna Reimondos, Iwu Utomo, Peter McDonald, and Terence Hull. 2016. "Transition Into Marriage In Greater Jakarta: Courtship, Parental Influence, And Self-Choice Marriage". South East Asia Research 1-18. doi: $10.1177 / 0967828 \times 16674134$

White, R, Wyn, J and Robards, B. 2017. Youth \& Society. Australia: Oxford University Press.

Woodman, D and Johanna Wyn. 2015a. Youth and Generation: Rethinking Change and Inequality in the Lives of Young People. London: Sage.

Woodman, D and Johanna Wyn. 2015b. "Class, Gender and Generation Matter: Using the Concept of Generation to Study Inequality and Social Change". Journal of Youth Studies 18(10): 1402-1410.

Wyn, J., Helen Cahill, Dan Woodman., Hernan Cuervo., Carmen Leccardi., and Jenny Chesters (Eds). 2020. Youth and the New Adulthood: Generations of Change. Singapore: Springer. 
